\author{
Marika Świeszczak*
}

\title{
ZAUFANIE DO SEKTORA BANKOWEGO
}

Streszczenie: Zaufanie jest podstawa relacji doradców $i$ klientów, ale przede wszystkim jest kapitałem niezbędnym do funkcjonowania banków jako instytucji zaufania publicznego. Celem niniejszego rozdziału jest próba umiejscowienia zaufania spotecznego $w$ teorii socjologicznej oraz. analiza opinii społeczeństwa na temat sektora bankowego oraz zaufania jako niezbędnej podstawy wspótpracy z instytucjami finansowymi.

Słowa kluczowe: zaufanie, banki, instytucja zaufania publicznego.

\section{WSTECP}

Pojęcie zaufania należy rozpatrywać na trzech poziomach - mikro, mezo i makro. Pierwszy z nich dotyczy tworzenia więzi międzyludzkich, niezbędnych do formułowania struktur organizacyjnych. Perspektywa mezostrukturalna obejmuje umiejętność współpracy międzyludzkiej w obrębie grup i organizacji, podejmowanej w celu realizacji wspólnych interesów. Co więcej, na tym poziomie należy mówić także o zaufaniu do instytucji, które uczestniczą w transakcjach wymiany i współpracy między członkami społeczeństwa ${ }^{1}$. Poziom makrostrukturalny obejmuje społeczne i polityczne otoczenie, sformalizowane instytucjonalne powiązania i struktury, zaś zaufanie ma w tym wypadku szczególne znaczenie dla prawidłowego funkcjonowania ustroju politycznego, norm prawnych, systemu sądownictwa oraz obywatelskich i politycznych uprawnień ${ }^{2}$.

Zaufanie jest fundamentem kapitału społecznego, ponieważ jest podstawą współpracy pomiędzy ludźmi. Można zatem powiedzieć, że przyczynia się do wzrostu dobrobytu społecznego, gdyż zwiększa się aktywność gospodarcza ${ }^{3}$. W odniesieniu do banków, zaufanie stanowi fundament relacji doradców i klientów, ale przede wszystkim dotyczy poczucia bezpieczeństwa, które jest niezbędne do przekonania konsumentów, by złożyli w banku swoje oszczędności.

\footnotetext{
* Dr Marika Świeszczak, Wydział Ekonomiczno-Socjologiczny, Uniwersytet Łódzki.

${ }^{1}$ W nawiązaniu do: J. S. Coleman, Social Capital in the Creation of Human Capital, „American Journal of Sociology" 1988, vol. 94, s. 95-120.

${ }^{2}$ W nawiązaniu do: D. North, Institutions, Institutional Change and Economic Performance, Cambrigde University Press, New York 1990; M. Olson, The Rise and Decline of Nations: Economic Growth, Stagflation and Social Rigidities, Yale University Press, New Haven 1982.

3 A. Matysiak, Źródła kapitału społecznego, Wydawnictwo Akademii Ekonomicznej we Wrocławiu, Wrocław 1999.
} 
Celem niniejszego rozdziału jest próba umiejscowienia zaufania społecznego w teorii oraz analiza opinii społeczeństwa na temat sektora bankowego oraz zaufania jako niezbędnej podstawy współpracy z instytucjami finansowymi.

\section{UMIEJSCOWIENIE POJECCIA ZAUFANIA SPOLECZNEGO W WYBRANYCH TEORIACH SOCJOLOGICZNYCH}

Rozważania na temat zaufania społecznego należy rozpocząć od jego pochodzenia. Występują dwie szkoły myślicieli na temat zaufania. Zgodnie ze stanowiskiem pierwszej, pojęcie to jest własnością każdego człowieka, związaną z jego indywidualnymi cechami osobowościowymi, cechami społecznymi i demograficznymi, takimi jak: klasy, wykształcenie, dochody, wiek i płeć. Druga szkoła podkreśla przynależność zaufania społecznego do kategorii systemu społecznego, koncentrującego się na właściwości społeczeństw i ich instytucji.

Początki szkoły myślicieli społeczno-psychologicznych, traktujących zaufanie jako podstawową cechę osobowości każdego człowieka, należy datować na lata 50. i 60. XX w. w Stanach Zjednoczonych ${ }^{4}$. Zgodnie z podstawowymi założeniami tej teorii, doświadczenia nabyte $\mathrm{w}$ dzieciństwie wpływają na zaufanie wobec świata i mają tendencję do utrwalania się na późniejszych etapach życia. Co istotne, zaufanie społeczne jest częścią szerszego syndromu cech osobowości, które obejmuje optymizm, wiarę we współpracę i zaufanie, że ludzie mogą przezwyciężyć różnice między nimi i żyć razem we wspólnocie. Podejście to było rozwijane w ostatnich czasach przez E. M. Uslanera, którego badania pokazują, że poziom zaufania każdego człowieka jest stabilny w czasie, a także że nie jest zależny od doświadczania wzajemności od drugiej osoby ${ }^{5}$. Rozwijane na przestrzeni lat rozważania E. H. Eriksona, G. W. Allporta, R. B. Cattella i E. M. Uslanera dały podstawy do stworzenia teorii osobowości, objaśniającej uwarunkowania zaufania. Podstawowym założeniem teorii jest to, że społeczne zaufanie wywodzi się od cech osobowościowych, szczególnie optymizmu i umiejętności kontroli własnego życia. Z drugiej strony pojawia się teoria sukcesu i dobrobytu, zgodnie z którą nieograniczone zaufanie niesie ze sobą ryzyko, które jest większe w przypadku biednych niż bogatych, gdyż ci pierwsi nie mogą sobie pozwo-

${ }^{4}$ Szerzej: E. H. Erikson, Childhood and Society, Norton, New York 1950; G. W. Allport, Pattern and Growth in Personality, Holt, Rinehart and Winston, New York 1961; R. B. Cattell, The Scientific Analysis of Personality, Penguin Books, Baltimore 1965; M. Rosenberg, Misanthropy and Political Ideology, „American Sociological Review” 1956, no. 21, s. 690-695; M. Rosenberg, Misanthropy and Attitudes Towards International Affairs, „Journal of Conflict Resolution" 1957, no. 1, s. 340-345.

${ }^{5}$ E. M. Uslaner, Democracy and Social Capital, [w:] M. Warren (red.), Democracy and Trust, Cambridge University Press, Cambridge 1999, s. 121-50; E. M. Uslaner, Producing and Consuming Trust, „Political Science Quarterly” 2000, no. 115(4), s. 569-590. 
lić na utratę posiadanych zasobów w przypadku zdrady. Zaufanie społeczne jest utożsamiane z postaciami „Zwycięzców” w społeczeństwie i jest mierzone w kategoriach pieniędzy, statusu i wysokiego poziomu zadowolenia z życia i pracy oraz szczęścia ${ }^{6}$. Praktycznie we wszystkich społeczeństwach biedni są mniej ufni niż bogaci, najprawdopodobniej ze względu na swoje wcześniejsze doświadczenia. Nieufność jest powszechniejsza wśród „przegranych”, czyli osób z niskim wykształceniem, niskimi dochodami i niskim statusem społecznym, którzy wyrażają niezadowolenie z życia. Co istotne, nieufność wyrażają także ofiary przestępstw, zbrodni, przemocy i osoby rozwiedzione. Zgodnie z tym poglądem, zaufanie społeczne jest produktem dorosłych doświadczeń życiowych - osoby, które doświadczyły pozytywnych doświadczeń, są bardziej skłonne do zaufania niż te, które doświadczyły ubóstwa, bezrobocia, przemocy, dyskryminacji, wyzysku czy wykluczenia ${ }^{7}$. Ten rodzaj interpretacji zaufania jest zgodny z teorią O. Pattersona, obejmującą analizę relacji między zaufaniem, klasami i rasami $w \mathrm{USA}^{8}$.

Drugim głównym podejściem do zaufania jest postrzeganie go jako własności społeczeństwa, a nie jednostek. Zaufanie jest rezultatem doświadczeń ludzi, ale jest stale modyfikowane, w zależności od zmieniających się okoliczności. Jednakże w przeciwieństwie do teorii indywidualnych pokazuje, jaki jest poziom zaufania do siebie $\mathrm{w}$ społeczeństwie ( $\mathrm{w}$ tym także jego wiarygodność) ${ }^{9}$. Jeśli w społeczeństwie funkcjonuje wiele różnych dobrowolnych stowarzyszeń i organizacji, to $\mathrm{w}$ świetle tej teorii może generować wysoki poziom zaufania społecznego. Teoria ta sięga do A. Tocqueville’a i J. S. Milla, zaś współcześnie jest centrum dyskusji na temat kapitału społecznego ${ }^{10}$. Jedną z jej form jest teoria organizacji wolontariatu, która wyróżnia bezpośrednie i trwałe zaangażowania $\mathrm{w}$ organizację wolontariatu w społeczności lokalnej jako najważniejszą formę

${ }^{6}$ G. Orren, Fall from Grace: The Public's Loss of Faith in Government, [w:] J. S. Nye, $\mathrm{Ph}$. D. Zelikow, D. C. King (red.), Why Americans Mistrust Government, Harvard University Press, Cambridge 1997; K. Newton, Social Capital and Democracy in Modern Europe, [w:] J. van Deth, M. Maraffi, K. Newton, P. Whiteley (red.), Social Capital and European Democracy, Routledge, London 1999, s. 3-24; P. F. Whiteley, The Origins of Social Capital, [w:] J. van Deth, M. Maraffi, K. Newton, P. Whiteley (red.), Social Capital and European Democracy, Routledge, London 1999, s. 25-44.

${ }^{7}$ R. Inglehart, Trust, Well-being and Democracy, [w:] M. E. Warren (red.), Democracy and Trust, Cambridge University Press, Cambridge 1999, s. 88-120; R. Putnam, Bowling Alone, The Collapse and Revival of American Community, Simon and Schuster, New York 2000.

${ }^{8}$ O. Patterson, Liberty Against the Democratic State: On the Historical and Contemporary Sources of American Distrust, [w:] M. E. Warren (red.), Democracy and Trust, Cambridge University Press, Cambridge 1999.

${ }_{9}^{9}$ R. Putnam, Bowling Alone, The Collapse..., s. 138; K. Newton., Trust, Social Capital, Civil Society, and Democracy, „International Political Science Review” 2001, no. 22(2), s. 201-14; R. Hardin, The Street-level Epistemology of Trust, „Politics and Society” 1993, no. 21, December, s. $505-29$.

${ }^{10}$ Szerzej: R. Putnam, Bowling Alone, The Collapse... 
uczestnictwa w społeczeństwie. Należy przy tym wskazać, że teoria ta jest szeroko krytykowana w literaturze ze względu na brak empirycznych dowodów na związek pomiędzy liczbą stowarzyszeń społecznych a zaufaniem społecznym ${ }^{11}$.

Niektórzy autorzy twierdzą, że bez względu na to, jak formalnie zorganizowane dobrowolne stowarzyszenia mogą być, ważne w pewnych aspektach, z punktu widzenia zaufania społecznego, jest bezpośrednie uczestnictwo w sieciach społecznościowych życia codziennego ${ }^{12}$. Dla większość ludzi oznacza to relacje rodzinne, przyjaciół, sąsiedztwo oraz udział w stosunkach społecznych w miejscu swojej pracy. Takie formy zaangażowania obywatelskiego i uczestnictwa w życiu społecznym są coraz częstszą formą w nowoczesnym społeczeństwie. Podejście to, znane jako teoria sieci społecznościowej, koncentruje się na zaufaniu do najbliższych osób, jako wyniku relacji pomiędzy nimi ${ }^{13}$.

Inną formą społecznej teorii zaufania jest teoria wspólnoty, koncentrująca się na charakterystyce lokalnych społeczności zamiast na nieformalnych sieciach społecznościowych w ich obrębie. Niektóre badania dowodzą, że im mniejsza jednostka miejska, tym większe jest zaufanie w jej obrębie. Najistotniejszymi zmiennymi w tej teorii jest rozmiar miasta, satysfakcja ze wspólnoty i panującego wewnątrz tej społeczności bezpieczeństwa (te dwie ostatnie zmienne wpływają wprost proporcjonalnie na wzrost zaufania $)^{14}$.

Ostatnia analizowana teoria (teoria społeczna) zakłada wpływ na zaufanie takich zmiennych, jak: konflikty społeczne (ich pojawianie się zmniejsza zaufanie społeczne), satysfakcja z demokratycznych instytucji (zależność wprost proporcjonalna), wolność polityczna (zależność wprost proporcjonalna) i bezpieczeństwo publiczne (zależność wprost proporcjonalna) ${ }^{15}$.

${ }^{11}$ J. Cohen, Trust, Voluntary Association and Workable Democracy, [w:] M. E. Warren (red.), Democracy and Trust, Cambridge University Press, Cambridge 1999, s. 208-248; K. Newton, Trust, Social Capital..., s. 201-214; P. Paxton, Social Capital and Democracy: An Interdependent Relationship, „American Sociological Review” 2002, no. 67, s. 254-277; M. Hooghe, Value Congruence within Voluntary Associations: Ethnocentrism in Belgian Organizations, Paper presented to the ECPR Joint Sessions of Workshops, Copenhagen 2000.

${ }^{12}$ T. Yamagishi, M. Yamagishi, Trust and Commitment in the United States and Japan, „Motivation and Emotion” 1993, no. 18(2), s. 129-166.

${ }^{13}$ S. Verba, K. L. Schlozman, H. E. Brady, Voice and Equality: Civic Volunteerism in American Politics, Harvard University Press, Cambridge 1995, s. 68-91; M. Schudson, What If Civic Life Didn't Die?, „The American Prospect” 1996, no. 25, March-April, s. 17-18.

${ }^{14} \mathrm{~J}$. S. House, Sh. Wolf, Effects of Urban Residence on Interpersonal Trust and Helping Behavior, „Journal of Personality and Social Psychology” 1978, no. 36, s. 1029-1043; R. Putnam, Bowling Alone, The Collapse..., s. 205; S. Knack, Ph. Keefer, Does Social Capital Have an Economic Payoff? A Cross-country Investigation, „Quarterly Journal of Economics” 1997, no. 112, s. $1282-1283$.

${ }^{15}$ J. Delhey, K. Newton, Who Trusts? The Origins of Social Trust in Seven Societies, „European Societies" 2003, no. 5(2), s. 99-100; O. Patterson, op. cit., s. 173; K. Newton, Trust, Social Capital..., s. 201-214. 


\section{DEFINICJA ZAUFANIA}

W literaturze można znaleźć wiele definicji zaufania. Perspektywa psychologiczna definiuje to pojęcie jako „całkowite zawierzenie komuś, wiara w kogoś, ufność" ${ }^{16}$, koncentrując się na emocjach w stosunku do drugiej osoby. Z kolei perspektywa socjologiczna skupia się na postrzeganiu zaufania w kontekście relacji międzyludzkich i znaczenia dla społeczeństwa. Spojrzenie to pozwala rozpatrywać analizowane pojęcie jako „wyrozumowaną kalkulację” (J. S. Coleman, R. Hardin) $)^{17}$, „efekt prawidłowej socjalizacji” (E. M. Uslaner) ${ }^{18}$ lub „efekt społecznego uczenia się" (A. Bandura) ${ }^{19}$. Przeciwstawną do tej pierwszej definicji znajdujemy u M. Andersona, według którego zaufanie jest normatywnym budowaniem relacji, przekładającej się na efektywność transakcji wymiany ${ }^{20}$, a zatem jest to stanowisko podkreślające konieczność odejścia od stanowiska wyrachowanego, opartego na maksymalizacji własnej korzyści, dla dobra całego społeczeństwa.

Nieco odmienne podejście można znaleźć u E. M. Uslandera i P. Sztompki, zgodnie z którym zaufanie jest „zakładem podejmowanym na temat niepewnych, przyszłych działań innych ludzi”"21, a także T. C. Earle'a i G. Cvetkivicha (,strategia upraszczająca, która pozwala jednostkom zaadoptować się do złożonego środowiska społecznego i tym samym korzystać z szerszej puli możliwości"22). Ta perspektywa badawcza występuje w publikacjach wielu autorów (m.in. B. Misztal, N. Lin, R. Hardin, L. Coote, E. J. Forrest i T. W. Tam), którzy przede wszystkim chcą zaakcentować oczekiwanie odnośnie działań innych osób ${ }^{23}$. Warte podkreślenia jest podejście akcentujące pozytywne intencje drugiej strony transakcji wymiany F. Fukuyamy - ,zaufanie to mechanizm oparty na założeniu, że innych członków danej społeczności cechuje uczciwe i kooperatywne

${ }^{16}$ E. Sobol (red.), Nowy stownik języka polskiego, Wydawnictwo Naukowe PWN, Warszawa 2002.

${ }^{17}$ J. S. Coleman, Foundations of Social Theory, Harvard University Press, Cambridge 1990; R. Hardin, Trust and Trustworthiness, Russell Sage Foundation, New York 2002.

${ }^{18}$ E. M. Uslaner, The Moral Foundations of Trust, Cambridge University Press, Cambridge 2002.

${ }^{19}$ A. Bandura, Teoria spolecznego uczenia się, Wydawnictwo Naukowe PWN, Warszawa 2007.

${ }^{20}$ Szerzej m.in. M. B. Katz, Essay Review: Family Structure in Nineteenth Century Lancashire. By Michael Anderson, „Journal of Social History” 1973, vol. 7, no. 1, s. 86-92.

${ }^{21}$ E. M. Uslaner, The Moral Foundations...; P. Sztompka, Zaufanie. Fundament spoteczeństwa, Znak, Kraków 2007, s. 69-70.

${ }^{22}$ T. C. Earle, G. Cvetkovich, Social Trust: Towards a Cosmopolitan Society, Praeger, Westport 1995.

${ }^{23}$ B. Misztal, Trust in Modern Societies: The Search for the Bases of Social Order, „Theory and Society", vol. 28, no. 2, s. 342-350; N. Lin, Social Capital. A Theory of Social Structure and Action, Cambridge University Press, Cambridge 2001; R. Hardin, Zaufanie, Wydawnictwo Sic, Warszawa 2009, s. 25; L. Coote, E. J. Forrest, T. W. Tam, An Investigation into Commitment in non-Western Industrial Marketing Relationships, „Industrial Marketing Management” 2003, vol. 32(7), s. 595-604. 
zachowanie oparte na wyznawanych normach”24 bądź też E. Głuszka - „traktowanie zaufania jako wiary w to, że żadna strona nie wykorzysta słabości tej drugiej, lub też jako wynik sankcji zniechęcających do zachowań oportunistycznych"25.

Pojęcie to może być także definiowane przez pryzmat jego wartości pragmatycznej, jak to czynił R. Inglehart, i wówczas jest rozumiane jako „nieformalna norma zmniejszająca koszty ekonomicznej transakcji, które tworzą nadzór nad zawieraniem kontraktów, rozsądzanie sporów i egzekwowanie formalnych porozumień" $^{26}$. W literaturze można też znaleźć rozważania wielu autorów na temat dziedziczenia zaufania, co w konsekwencji pokazuje wpływ kultury na jego wartość (F. Fukuyama, R. D. Putnam, L. Guiso, P. Sapienza, L. Zingales) ${ }^{27}$.

Zaufanie może być także definiowane w kontekście rozważań na temat kapitału społecznego, zaś wśród wielu badaczy można znaleźć stanowisko, że jest ono jego najistotniejszym komponentem. Zdaniem R. Putnama zaufanie w społeczeństwie wpływa wprost proporcjonalnie na podejmowanie współpracy między członkami społeczeństwa, zaś według G. Poggi’ego jest to także czynnik warunkujący jego trwałośćc ${ }^{28}$.

Pojęcie zaufania można rozpatrywać $\mathrm{z}$ dwóch płaszczyzn badawczych: jako niepodzielną całość (,społecznie nabyte i potwierdzone oczekiwania, jakie ludzie żywią wobec siebie nawzajem, wobec instytucji i organizacji, wśród których żyją, oraz wobec moralnych reguł życia społecznego, które ustalają podstawowe zasady ich życia" ${ }^{29}$ ), bądź też w odniesieniu do jednostek (,,prawidłowe przewidywanie działań innych ludzi, które mają wpływ na działania jednostki w sytuacji, gdy wybór działania musi zostać dokonany, zanim możliwe będzie zaobserwowanie działań innych osób" ${ }^{\text {30 }}$ ). Nieco inną klasyfikację zaufania przedstawił E. C. Uslander (w zależności od sposobu definiowania i różnicowania zaufania $)^{31}$ :

- strategiczne - prognoza zachowania drugiej osoby, opiera się na wiedzy (zdobytych informacjach i osobistych doświadczeniach) i ma pomóc w opracowaniu strategii decyzyjnej;

${ }^{24}$ F. Fukuyama, Zaufanie. Kapitat społeczny a droga do dobrobytu, Wydawnictwo Naukowe PWN, Warszawa 1997, s. 38.

${ }^{25}$ E. Głuszek, Zaufanie jako istotny składnik kapitału intelektualnego przedsiębiorstwa, „Prace Naukowe Akademii Ekonomicznej we Wrocławiu” 2002, nr 963, s. 123-124.

${ }^{26}$ R. Inglehart, op. cit.

${ }^{27}$ Szerzej: F. Fukuyama, op. cit., s. 38; R. D. Putnam, Bowling Alone. The Collapse...; L. Guiso, P. Sapienza, L. Zingales, Social Capital as Good Culture, „Journal of the European Economic Association" 2008, vol. 6, no. 2-3.

${ }^{28}$ R. Putnam, Demokracja $w$ działaniu: tradycje obywatelskie we współczesnych Włoszech, Znak, Kraków 1995, s. 264, 265.

${ }^{29}$ B. Barber, The Logic and Limits of Trust, Rutgers University Press, New Brunswick 1983.

${ }^{30}$ P. Sztompka, Zaufanie. Fundament..., s. 71.

${ }^{31}$ E. C. Uslander, Zaufanie strategiczne i zaufanie normatywne, [w:] P. Sztompka, M. Boguni-Borowska (red.), Socjologia codzienności, Znak, Kraków 2008, s. 184-189. 
- normatywne - postawa moralna nabyta w procesie socjalizacji, ma formę uogólnionego założenia na temat dobrej woli drugiej osoby, co w konsekwencji uzasadnia wybór strategii kooperacji podczas wspólnie podejmowanych działań.

Najobszerniejsza klasyfikacja, zaproponowana przez P. Sztompkę, obejmuje następujące rodzaje zaufania, w zależności od adresatów ${ }^{32}$ :

- osobiste (międzyosobowe, interpersonalne) - skierowane jest do konkretnych osób, z którymi zachodzą interakcje. W grupie tej znajdują się: rodzina (największy poziom zaufania), przyjaciele, znajomi, sąsiedzi, koledzy z pracy, partnerzy w interesach, osoby, które znamy i z którymi mamy jakiekolwiek relacje;

- społeczne - obejmujące grupę ludzi szerszą niż najbliższe otoczenie danej osoby, pomiędzy członkami społeczności nie zachodzą relacje interpersonalne;

- pozycyjne - skierowane do określonych ról społecznych, zawodów, urzędów i stanowisk. Relacje wynikają z określonej pozycji społecznej, pełnienia instytucjonalnej roli, zaś zaufanie wzbudza jej profesjonalne pełnienie i postępowanie zgodnie ze standardami, normami i przepisami wymaganymi na danym stanowisku;

- publiczne - skierowane do instytucji i organizacji, pojmowanych jako zbiory reguł strukturalnych, w których zachodzą określone interakcje. Co istotne, nie jest konieczny bezpośredni kontakt z tym adresatem;

- technologiczne - obejmują zaufanie do różnego rodzaju systemów technicznych, systemów urządzeń technicznych czy też kompetencji zawodowych, które umożliwiają funkcjonowanie całego społeczeństwa;

- komercyjne - pośrednio związane z relacją klient-instytucja. Skierowane jest do produktu (wyrobu, usługi) konkretnej marki, firmy czy państwa;

- $\quad$ systemowe - kierowana do systemu, np. gospodarki, ustroju, cywilizacji.

Zaufanie społeczne wobec osób jest określane jako zaufanie poziome ${ }^{33}$, do którego może odnosić się także zaufanie moralne (rozpatrywane w kategoriach kulturowych, wynikające z oczekiwań i odczuć o charakterze moralnym). Do zaufania pionowego stosuje się zwykle zaufanie racjonalne, oparte na racjonalnych oczekiwaniach ${ }^{34}$.

\section{UWARUNKOWANIA ZAUFANIA SPOLECZNEGO}

Czynniki wpływające na zaufanie można pogrupować według trzech kategorii: tradycja historyczna (jest to tzw. zmienna tła), kontekst strukturalny (obejmujący spoistość normatywną, stabilność porządku społecznego, przejrzystość organizacji społecznej, „oswojenie” otoczenia społecznego, odpowiedzial-

\footnotetext{
${ }^{32}$ P. Sztompka, Socjologia. Analiza społeczeństwa, Znak, Kraków 2002, s. 229.

${ }^{33}$ R. Inglehart, op. cit.

${ }^{34}$ D. Walczak-Duraj, Socjologia dla ekonomistów, PWE, Warszawa 2010, s. 83.
} 
ność osób i instytucji) i wyposażenie podmiotowe (nastroje społeczne: impuls zaufania, aktywizm, oportunizm, orientacja na przyszłość, wysokie aspiracje, orientacja na sukces, oraz społeczne zasoby kapitałowe: zamożność, bezpieczeństwo zatrudnienia, wielkość ról, posiadana władza, sieć społecznych więzi, stabilność rodzinna, religijność) ${ }^{35}$.

W literaturze można także znaleźć następujące uwarunkowania zaufania ${ }^{36}$ :

- homogeniczność grupy (im jest ona większa, tym wyższy poziom zaufania) $)^{37}$,

- egalitarna/liberalna dystrybucja dochodów w społeczeństwie (egalitarna dystrybucja wpływa na wzrost zaufania),

- występowanie praktyk dyskryminacyjnych (wpływają one na spadek poziomu zaufania),

- gwałtowne zmiany porządku społecznego (im są one gwałtowniejsze, tym niższy jest poziom zaufania) $)^{38}$

- zmiany o charakterze modernizacyjnym (wpływają one na wzrost poziomu zaufania),

- globalizacja,

- liczba powiązań pomiędzy członkami sieci społecznej (im jest ona większa, tym wyższy poziom zaufania) ${ }^{39}$,

- wzrost i stopień skomplikowania społeczności (im są one większe, tym niższy poziom zaufania) ${ }^{40}$,

- pojawienie się społeczeństwa wielokulturowego, mogące doprowadzić do zachwiania podstaw jednostkowej tożsamości (wpływają one na spadek poziomu zaufania),

- nietrwałość sytuacji życiowej (wpływają one na spadek poziomu zaufania),

- poczucie zagrożenia wynikające z zagrożeń terrorystycznych (wpływają one na spadek poziomu zaufania).

Badania dotyczące zaufania obejmują następujące grupy czynników ${ }^{41}$ :

- statusowe (wykształcenie, pozycja zawodowa, dochód/status materialny),

- relacyjne (członkostwo w grupach nieformalnych, organizacjach i stowarzyszeniach, ruchliwość przestrzenna, aktywność społeczna),

- środowiskowe (więź ze środowiskiem zamieszkania, opinie o nim, jego cechy charakterystyczne),

- instytucjonalne (ocena instytucji, poziom alienacji politycznej),

\footnotetext{
${ }^{35}$ P. Sztompka, Trust. The Sociological Theory, Cambridge University Press, Cambridge 1999.

${ }^{36}$ D. Walczak-Duraj, op. cit., s. 86.

${ }^{37} \mathrm{M}$. Anderson, op. cit.

${ }^{38}$ Ibidem.

${ }^{39}$ Ibidem.

${ }^{40}$ Ibidem.

${ }^{41}$ D. Walczak-Duraj, op. cit., s. 86-87.
} 
- psychospołeczne (zadowolenie z życia, optymizm/pesymizm, poziom lęku i frustracji, preferencje indywidualistyczne lub kolektywistyczne),

- kulturowe (poziom akceptacji norm etycznych, stosunek do tradycji, religijność, samodzielność/roszczeniowość, tolerancja/ksenofobia).

Co istotne, kierunek i siła zależności poszczególnych czynników na poziom zaufania może być różny w zależności od grupy badawczej oraz podjętego problemu badawczego.

\section{BANK JAKO INSTYTUCJA ZAUFANIA PUBLICZNEGO}

Banki jako instytucje pośrednictwa finansowego pełnią w systemie finansowym szczególną rolę - zapewniają obrót instrumentów finansowych, przejmują na siebie ryzyko, udostępniają informacje o stopniu ryzyka oraz mają dostęp do pożyczkodawcy ostatniej instancji ${ }^{42}$. Oprócz wymienionych, podmioty te realizują jeszcze jedno szczególnie istotne zadanie - znacząco przyczyniają się do utrzymania stabilności systemu bankowego, czyli mają zapobiegać sytuacjom, w których mechanizmy oceny, alokacji środków i zarządzania ryzykiem finansowym nie są sprawne ${ }^{43}$. Stąd też od lat czynione są działania, które mają na celu zapewnić równowagę pomiędzy efektywnością i stabilnością. Uznanie stabilności finansowej za dobro publiczne przyczyniło się do podjęcia czynności, mających na celu zbudowanie sieci bezpieczeństwa finansowego, poprzez takie działania jak ${ }^{44}$ :

- wydawanie koncesji i zezwoleń,

- nadzór ostrożnościowy,

- wycofywanie licencji,

- gwarantowanie depozytów,

- ochrona zaufania do sektora bankowego,

- pełnienie funkcji pożyczkodawcy ostatniej instancji,

- ingerencja władz monetarnych.

Należy zwrócić szczególną uwagę na działania mające na celu zapewnienie ochrony zaufania do sektora bankowego - czynności te mają ogromne znaczenie dla funkcjonowania wszystkich banków, które opiera się właśnie na zaufaniu

${ }^{42}$ M. Iwanicz-Drozdowska, Typologia i tendencje rozwojowe systemów gwarantowania depozytów, [w:] M. Iwanicz-Drozdowska (red.), Systemy gwarantowania depozytów w Polsce i na świecie, PWE, Warszawa 2005, s. 446

${ }^{43}$ J. Osiński, Stabilność finansowa w Polsce - aspekty finansowe, „Bank i Kredyt” 2005, nr 11-12, s. 4-5.

${ }^{44}$ A. Santomero, Deposit Insurance: Do We Need It and Why, The Wharton School, University of Pensylvania, Pensylvania 1997, s. 11-12. 
klientów do instytucji finansowych ${ }^{45}$. Sprawne działanie systemu bankowego wymaga zdobycia i utrzymania wiary przedsiębiorstw i osób fizycznych w to, że ich oszczędnościom zostanie zapewnione bezpieczeństwo. Ze względu na zaufanie, którym klienci obdarzają banki, są one traktowane jako instytucje zaufania publicznego $^{46}$. Prowadząc działalność opartą na depozytach banki muszą brać pod uwagę nie tylko własne interesy, ale także (lub raczej przede wszystkim) interesy społeczeństwa ${ }^{47}$. Etyczne postępowanie instytucji finansowych buduje zaufanie klientów, zwiększa ufność kontrahentów oraz tworzy renomę banków. Inną przesłanką wpływającą na kreowanie statusu banków jako instytucji zaufania publicznego jest tajemnica bankowa, chroniąca interes ekonomiczny banków i ich klientów ${ }^{48}$.

Z drugiej jednak strony banki są instytucjami, które prowadzą działalność usługową w sposób analogiczny do zwykłych przedsiębiorstw. Oznacza to, że ich podstawowym celem jest maksymalizacja zysków ${ }^{49}$. Pogląd ten jest bardzo popularny w literaturze - przykładowo A. Smith twierdził, że „każdy człowiek czyni stale wysiłki, by znaleźć najbardziej korzystne zastosowanie dla kapitału, jakim może rozporządzać, przy czym ma on na widoku własną korzyść, a nie korzyść społeczeństwa" ${ }^{, 50}$. Autorzy próbując określić zasady działania podmiotów niejednokrotnie podkreślali związek pomiędzy działaniem a maksymalizacją korzyści w dłuższym okresie ${ }^{51}$. Niemniej przy tak przedstawionych definicjach konieczne jest określenie, kto jest beneficjentem tych zysków - i także w tym temacie badacze są podzieleni, gdyż w literaturze wymienia się zarówno instytucje, jak i właścicieli czy akcjonariuszy ${ }^{52}$. Liczne przykłady literaturowe dowodzą, że znaczna część ekonomistów uznawała przede wszystkim własne zyski za motyw działania, stąd też gospodarowanie opierało się na zasadach racjonalności, a nie etyki.

Niemniej w literaturze (m.in. J. W. Gałkowski) można spotkać się z opinią odwrotną, zgodnie z którą maksymalizacja zysku nie powinna być jedynym lub najważniejszym kryterium działania właściciela, gdyż nie jest najwyższą wartością - celem funkcjonowania przedsiębiorstw (w tym także bankowych) jest

${ }^{45}$ B. Zdanowicz, Podstawowe dylematy i kryteria wyboru formuly systemu gwarantowania depozytów w świetle teorii i doświadczeń międzynarodowych, „Bezpieczny Bank” 2007, nr 1(34), s. 12.

${ }^{46}$ E. Fojcik-Mastalska, Prawo bakowe. Komentarz, LexisNexis, Warszawa 2005.

${ }^{47}$ L. Góral, Nadzór bankowy, PWE, Warszawa 1998, s. 29.

${ }^{48}$ J. Majewski, Prawo karne gospodarcze, [w:] O. Górniok (red.), Prawo karne gospodarcze. Prawo gospodarcze i handlowe, C. H. Beck, Warszawa 2003, s. 296.

${ }^{49}$ A. Janiak, O przywilejach bankowych. Cz. III, „Prawo Bankowe” 2000, nr 11, s. 59.

50 A. Smith, Badania nad natura i przyczynami bogactwa narodów, t. 2, PWN, Warszawa 1954, s. 42-43.

${ }^{51}$ Szerzej: E. Stenberg, Czysty biznes. Etyka $w$ działaniu, Wydawnictwo Naukowe PWN, Warszawa 1998; J. Sekuła, Uprawomocnienie tzw. etyki biznesu w systemie etyki graduacyjnej, [w:] A. Węgrzecki (red.), Etyczne fundamenty gospodarowania, Oficyna Cracovia, Kraków 1999, s. 37.

${ }^{52}$ J. Bocheński, Filozofia przedsiębiorstwa, [w:] J. Bocheński (red.), Sens życia i inne eseje, Wydawnictwo Antyk, Kraków 1993, s. 72. 
zaspokajanie materialnych (a pośrednio także duchowych) potrzeb społeczeństwa, zarówno obecnych, jak i przyszłych ${ }^{53}$. Ten punkt widzenia jest w literaturze rzadziej spotykany, lecz wnosi do rozważań na temat celu działania podmiotu istotną wartość - ocenę moralną motywów działania właścicieli, piętnującą podejście nastawione wyłącznie na zysk.

W związku z tym powstaje konieczność osiągnięcia równowagi pomiędzy efektywnością (konkurencyjnością, dochodowością, itp.) a bezpieczeństwem klientów (stabilnością, etyką, zaufaniem, itp.). Co istotne, znalezienie tego kompromisu nie jest działaniem jednorazowym, a raczej czynnością powtarzaną wielokrotnie ze względu na stale zmieniające się warunki rynkowe. Wypracowywanie zysków jest ważne dla przetrwania banków na rynku, ale realizacja tego celu jest ściśle uzależniona od zaufania klientów. Zatem obok dążenia do podnoszenia efektywności działania konieczne jest również zapewnianie bezpieczeństwa depozytów, co jest możliwe poprzez prowadzenie działalności w sposób etyczny, czyli zgodny z przyjętymi normami moralnymi.

Charakter relacji oparty na zaufaniu sprowadza się do określonych norm, zasad i wartości etycznych, które stają się podstawą ich budowania. Można tu mówić o mechanizmie, którego fundamentem jest przeświadczenie o tym, iż dana społeczność cechuje się uczciwym i kooperatywnym zachowaniem. Stosunek ten oparty jest na wzajemnym poszanowaniu dla określonych norm ${ }^{54}$. Jest to szczególnie istotne w kontekście sektora bankowego, którego relacje, zwłaszcza z klientami, oparte są na szczególnym, społecznym wymiarze zaufania.

Rola, jaką banki odgrywają dla kształtowania ładu społeczno-gospodarczego, wynika m.in. z powszechnego dostępu do produktów i usług bankowych, które tym samym bardzo często są utożsamiane $\mathrm{z}$ usługami publicznymi ${ }^{55}$ oraz $\mathrm{z}$ faktu zarządzania powierzonymi im środkami przez klientów ${ }^{56}$. Banki pełnią $\mathrm{w}$ ten sposób rolę publicznego depozytariusza, co sprawia, iż przedsiębiorstwa bankowe podlegają powszechnej ocenie wiarygodności i zaufania.

W przypadku instytucji zaufania publicznego, do których należą banki, owe zaufanie publiczne jest kreowane oraz wzmacniane poprzez jego gwarantowanie przez państwo. Wspomniane gwarancje mogą mieć dwojaki charakter ${ }^{57}$ :

- prawny - będący konsekwencją obowiązujących przepisów prawa;

- instytucjonalny - związany z działaniem organów, którym państwo powierzyło określone zadania.

${ }^{53}$ J. W. Gałkowski, Zasady etyki zawodowej - etyka biznesu, [w:] M. Borkowska, J. W. Gałkowski (red.), Etyka w biznesie, TN KUL, Lublin 2002, s. 42.

${ }^{54}$ F. Fukuyama, op. cit., s. 38.

${ }^{55}$ L. Góral, op. cit., s. 169.

${ }^{56}$ B. Pietrzak, Z. Polański (red.), System finansowy w Polsce, Wydawnictwo Naukowe PWN, Warszawa 1998, s. 39.

${ }^{57}$ E. Radziszewski, Bank jako instytucja zaufania publicznego. Gwarancje prawne i instytucjonalne, KNF, Warszawa 2013, s. 10. 
Bankowość określa się mianem dobra publicznego, co wynika z dualnego charakteru banków - z jednej strony są klasycznymi przedsiębiorstwami usługowymi, a z drugiej powinny być instytucjami zaufania publicznego ${ }^{58}$. Pełnienie tej szczególnej funkcji wynika ze szczególnych rygorów prawnych, pod którymi instytucje te prowadzą działalność, a w konsekwencji z rygorystycznego nadzoru nad ich funkcjonowaniem ${ }^{59}$. Najistotniejsze argumenty wskazujące na posiadanie przez bank statusu instytucji zaufania publicznego zawiera tab. 1 .

Przepisy prawa obejmują zarówno utworzenie, jak i działanie i likwidację banków, zatem na każdym etapie życia instytucje te są objęte szczególnym nadzorem. Co istotne, prawo $\mathrm{w}$ ten sposób chroni interes publiczny (rozumiany jako powierzone przez klientów oszczędności), ponieważ nakazuje przedsiębiorstwom bankowym działać w sposób chroniący ich interesy (np. poprzez lokowanie depozytów w bezpieczne oszczędności, utrzymywanie kapitałów własnych na określonym poziomie, tak aby była możliwa wypłata środków klientów w dowolnym momencie, itd.). Wszystko to powoduje, że banki różnią się od standardowych przedsiębiorstw usługowych, a ich działalność nie ogranicza się wyłącznie do sprzedaży usług bankowych. Ponadto należy wspomnieć o innym szczególnie ważnym aspekcie prowadzonych rozważań - instytucje finansowe mają bezpośredni wpływ na funkcjonowanie i stabilność gospodarki ze względu na to, że dostarczają płynności różnym podmiotom. Co istotne, dokonując transakcji kredytowych, inwestycyjnych czy lokacyjnych banki przejmują część ryzyka takiego przedsięwzięcia, co także odróżnia je od pozostałych przedsiębiorstw usługowych oraz świadczy o trosce o dobro publiczne ${ }^{60}$.

\section{ZAUFANIE DO POLSKIEGO SEKTORA BANKOWEGO W ŚWIETLE BADAŃ EMPIRYCZNYCH}

Na przestrzeni lat 2007-2014 można zauważyć wzrost pozytywnej opinii o polskim sektorze bankowym, zarówno pod względem wzrostu opinii bardzo i raczej dobrych, jak również spadku bardzo i raczej niedobrych (zob. wykres 1). Co istotne, w okresie kryzysu gospodarczego można zauważyć wyraźne pogorszenie opinii społeczeństwa.

${ }^{58}$ S. Flejterski, W poszukiwaniu nowego paradygmatu zarządzania przedsiębiorstwem bankowym, [w:] A. Panasiuk, K. Rogoziński (red.), Zarządzanie organizacjami usługowymi, Wydawnictwo Uniwersytetu Ekonomicznego w Poznaniu, Poznań 2009.

59 M. Dąbrowska, Bank jako instytucja zaufania publicznego, „Bezpieczny bank” 2002, nr 2-3(17-18), s. 137.

${ }^{60}$ D. Czarnota, Bank jako instytucja zaufania publicznego $w$ dobie kryzysu - mit czy rzeczywistość?, „Zeszyty Naukowe Wydziałowe Uniwersytetu Ekonomicznego w Katowicach. Studia Ekonomiczne" 2014, nr 186, s. 154-155 
Tabela 1. Argumenty wskazujące na posiadanie przez bank statusu instytucji zaufania publicznego

\begin{tabular}{|c|c|c|}
\hline Autor & Argument & $\begin{array}{c}\text { Ustawa, } \\
\text { przepis prawny, itp. }\end{array}$ \\
\hline 1 & 2 & 3 \\
\hline $\begin{array}{l}\text { E. Fojcik- } \\
\text {-Mastalska }\end{array}$ & $\begin{array}{l}\text { Ustawodawca określa warunki podjęcia działal- } \\
\text { ności bankowej w celu zapewnienia bezpieczeń- } \\
\text { stwa i profesjonalizmu w działalności powstają- } \\
\text { cego banku. }\end{array}$ & $\begin{array}{l}\text { Ustawa Prawo bankowe, } \\
\text { art. } 30 .\end{array}$ \\
\hline K. Płończyk & $\begin{array}{l}\text { Ustawodawca nakłada sankcje za prowadzenie } \\
\text { działalności bankowej bez zezwolenia w celu } \\
\text { ochrony obywateli oraz interesu samego banku. }\end{array}$ & $\begin{array}{l}\text { Ustawa Prawo bankowe, } \\
\text { art. } 171 .\end{array}$ \\
\hline & $\begin{array}{l}\text { Ustawodawca zobowiązuje bank do posiadania } \\
\text { i utrzymywania funduszy własnych banku. }\end{array}$ & $\begin{array}{l}\text { Ustawa Prawo bankowe, } \\
\text { art. } 126-128 .\end{array}$ \\
\hline L. Góral & $\begin{array}{l}\text { Ustawodawca upoważnia Bankowy } \text { Fundusz } \\
\text { Gwarancyjny do udzielania pomocy bankom } \\
\text { w przypadku powstania niebezpieczeństwa } \\
\text { niewypłacalności. }\end{array}$ & $\begin{array}{l}\text { Ustawa o Bankowym } \\
\text { Funduszu Gwarancyjnym. }\end{array}$ \\
\hline \multirow{3}{*}{ K. Kohutek } & $\begin{array}{l}\text { Ustawodawca wprowadził umowę agencyjną } \\
\text { (jako podstawę do powierzenia przez bank osobie } \\
\text { trzeciej wykonywania określonych czynności } \\
\text { bankowych - tj. outsourcingu) w celu zagwaran- } \\
\text { towania bezpieczeństwa finansowego banku. }\end{array}$ & $\begin{array}{l}\text { Ustawa Prawo bankowe, } \\
\text { art. } 6 \text { a. }\end{array}$ \\
\hline & $\begin{array}{l}\text { Ustawodawca wprowadził warunki, od których } \\
\text { uzależniona jest możliwość posłużenia się przez } \\
\text { bank outsourcingiem. }\end{array}$ & $\begin{array}{l}\text { Ustawa Prawo bankowe, } \\
\text { art. } 6 \mathrm{c} .\end{array}$ \\
\hline & $\begin{array}{l}\text { Ustawodawca wprowadził możliwość ustano- } \\
\text { wienia zarządu komisarycznego w celu prze- } \\
\text { prowadzenia prawidłowego postępowania na- } \\
\text { prawczego. }\end{array}$ & $\begin{array}{l}\text { Ustawa Prawo bankowe, } \\
\text { art. } 145 .\end{array}$ \\
\hline M. Bączyk & $\begin{array}{l}\text { Ustawodawca nadaje dokumentom bankowym } \\
\text { moc prawną dokumentu urzędowego. }\end{array}$ & $\begin{array}{l}\text { Ustawa Prawo bankowe, } \\
\text { art. } 95 .\end{array}$ \\
\hline $\begin{array}{l}\text { J. Majewski, } \\
\text { Z. Ofiarski, } \\
\text { J. Molis }\end{array}$ & $\begin{array}{l}\text { Ustawodawca zobowiązuje banki do przestrzega- } \\
\text { nia tajemnicy bankowej w celu ochrony intere- } \\
\text { sów ekonomicznych klientów i banków (kreacja } \\
\text { prestiżu banków). }\end{array}$ & $\begin{array}{l}\text { Ustawa Prawo bankowe, } \\
\text { art. } 104 .\end{array}$ \\
\hline P. Masiukiewicz & $\begin{array}{l}\text { Ustawodawca zobowiązuje banki do lokowania } \\
\text { powierzonych im środków pieniężnych w pewne } \\
\text { aktywa. }\end{array}$ & $\begin{array}{l}\text { Ustawa Prawo bankowe, } \\
\text { Ustawa o obrocie instru- } \\
\text { mentami finansowymi. }\end{array}$ \\
\hline M. Zdyb & $\begin{array}{l}\text { Ustawodawca zapewnia bankom ochronę po- } \\
\text { przez penalizację czynów polegających m.in. na } \\
\text { wyłudzaniu kredytów, gwarancji bankowych, } \\
\text { dotacji, subwencji, zamówień publicznych czy } \\
\text { „prania brudnych pieniędzy”. }\end{array}$ & $\begin{array}{l}\text { Prawo karne, Ustawa } \\
\text { o przeciwdziałaniu praniu } \\
\text { pieniędzy oraz finanso- } \\
\text { waniu terroryzmu. }\end{array}$ \\
\hline R. Kałużny & $\begin{array}{l}\text { Ustawodawca poddał banki pod specjalny nad- } \\
\text { zór, co wiąże się z podwyższonymi wymagania- } \\
\text { mi co do profesjonalizmu ich działania przy } \\
\text { jednocześnie większej odpowiedzialności za } \\
\text { efekty dokonywanych czynności. }\end{array}$ & $\begin{array}{l}\text { Ustawa o nadzorze nad } \\
\text { rynkiem kapitałowym } \\
\text { - nadzór KNF. }\end{array}$ \\
\hline
\end{tabular}


Tabela 1 (cd.)

\begin{tabular}{|c|c|c|}
\hline 1 & 2 & 3 \\
\hline H. Dzwonkowski & $\begin{array}{l}\text { Banki posiadają autorytet, który utrwalił się na } \\
\text { przestrzeni lat. }\end{array}$ & Zwyczaj. \\
\hline $\begin{array}{l}\text { J. Głuchowski, } \\
\text { J. Szambelańczyk }\end{array}$ & $\begin{array}{l}\text { Banki cieszą się ogromnym zaufaniem klientów. } \\
\text { Deponenci powierzając bankom swoje środki } \\
\text { pieniężne wierzą, że są one bezpieczne, nie stracą } \\
\text { na wartości, oraz że będą mogli je wypłacić } \\
\text { w dowolnym bądź określonym w umowie } \\
\text { terminie. }\end{array}$ & \multirow[t]{2}{*}{ Zaufanie. } \\
\hline $\begin{array}{c}\text { Trybunał } \\
\text { Konstytucyjny }\end{array}$ & $\begin{array}{l}\text { Banki gromadzą środki pieniężne znacznej liczby } \\
\text { osób. }\end{array}$ & \\
\hline $\begin{array}{l}\text { Związek Banków } \\
\text { Polskich }\end{array}$ & $\begin{array}{l}\text { Banki, jako instytucje zaufania publicznego } \\
\text { w swojej działalności kierują się przepisami } \\
\text { prawa, rekomendacjami Komisji Nadzoru Finan- } \\
\text { sowego, uchwałami samorządu bankowego, } \\
\text { normami przewidzianymi w Kodeksie oraz do- } \\
\text { brymi zwyczajami kupieckimi. Banki i ich pra- } \\
\text { cownicy oraz osoby, za których pośrednictwem } \\
\text { banki wykonują czynności bankowe, uwzględnia- } \\
\text { ją zasady: profesjonalizmu, rzetelności, rzeczo- } \\
\text { wości, staranności i najlepszej wiedzy. }\end{array}$ & Kodeks Etyki Bankowej \\
\hline
\end{tabular}

Źródło: M. Bączyk, L. Góral, E. Fojcik-Mastalska (red.), Prawo bankowe. Komentarz, Wydawnictwo Prawo i Gospodarka, Warszawa 2005; F. Zoll (red.), Prawo bankowe. Komentarz, Kantor Wydawniczy Zakamycze, Zakamycze 2005; J. Pitera, Charakterystyka instytucji zaufania publicznego $w$ orzecznictwie Trybunału Konstytucyjnego, Sądu Najwyższego oraz Sądów Powszechnych, „Kwartalnik Prawa Publicznego” 2007, nr 4, s. 149-150, Ustawa z dnia 14 grudnia 1994 r. o Bankowym Funduszu Gwarancyjnym, DzU 1994, nr 4, poz. 18, ze zm.; Uchwała Izby Cywilnej SN z 30.04.1999 r., III CZP 61/98. OSNC 1999, nr 12, poz. 201; O. Górniok (red.), Prawo karne gospodarcze. Prawo gospodarcze i handlowe, C. H. Beck, Warszawa 2003, s. 296; Z. Ofiarski, Prawo bankowe, Kantor Wydawniczy Zakamycze, Zakamycze 2004, s. 205-212; P. Masiukiewicz, Rola państwa w przezwyciężaniu kryzysu banku, [w:] J. Szambelańczyk (red.), Globalny kryzys finansowy $i$ jego konsekwencje $w$ opiniach ekonomistów polskich, Związek Banków Polskich, Warszawa 2009; Ustawa z dnia 29 lipca 2005 r. o obrocie instrumentami finansowymi, DzU 2005, $\mathrm{nr}$ 183, poz. 1538, ze zm.; Ustawa z dnia 6 czerwca 1997 r. Prawo karne, DzU 1997, nr 88, poz. 553, ze zm.; Ustawa z dnia 16 listopada 2000 r. o przeciwdziałaniu praniu pieniędzy oraz finansowaniu terroryzmu, DzU 2000, nr 116, poz. 1216, ze zm.; R. Kałużny, Skutki kryzysu. Nowe spojrzenie na rolę banków, [w:] A. Janc (red.), Bankowość a kryzys na rynkach finansowych, Wydawnictwo Uniwersytetu Ekonomicznego w Poznaniu, Poznań 2010, s. 526; Ustawa z dnia 29 lipca 2005 r. o nadzorze nad rynkiem kapitałowym, DzU 2005, nr 183, poz. 1537, ze zm.; C. Kosikowski, H. Dzwonkowski, A. Huchla, Ustawa Ordynacja podatkowa. Komentarz, C. H. Beck, Warszawa 2002; J. Głuchowski, J. Szambelańczyk, Bankowość: podręcznik dla studentów, Wydawnictwo Wyższej Szkoły Bankowej, Poznań 1999, s. 425; Wyrok Trybunatu Konstytucyjnego z 18.04.2000 r., K 23/99, „Glosa” 2000, nr 12, s. 47; OTK ZU 2000, nr 3, poz. 89 [za:] D. Czarnota, Bank jako instytucja zaufania publicznego $w$ dobie kryzysu - mit czy rzeczywistość?, „Zeszyty Naukowe Wydziałowe Uniwersytetu Ekonomicznego w Katowicach. Studia Ekonomiczne” 2014, nr 186, s. 154-155; Kodeks Etyki Bankowej, Związek Banków Polskich, Warszawa 2013, s. 3. 


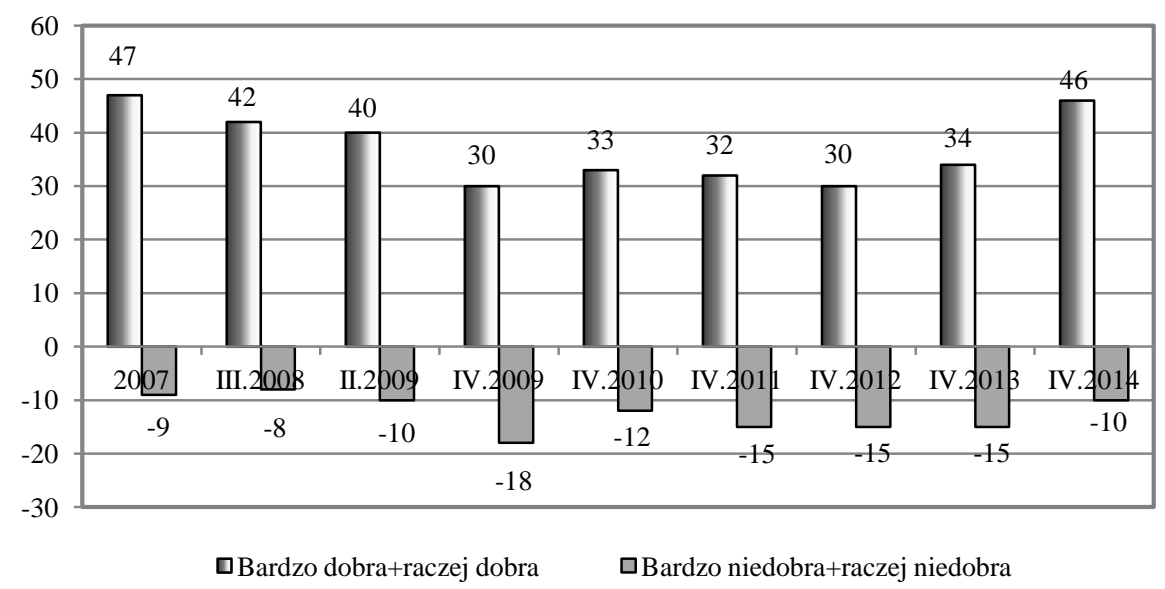

Wykres 1. Opinia społeczeństwa na temat polskiego sektora bankowego (w \% odpowiedzi)

Źródło: opracowanie własne na podstawie: Wizerunek polskiego sektora bankowego. Edycja 2014, TNS Polska dla Związku Banków Polskich, Warszawa 2014, s. 12.

Badając opinię publiczną na przestrzeni lat 2012-2014 można zauważyć wzrost pozytywnych poglądów na temat sektora bankowego i zaufania do banków (wykres 2).

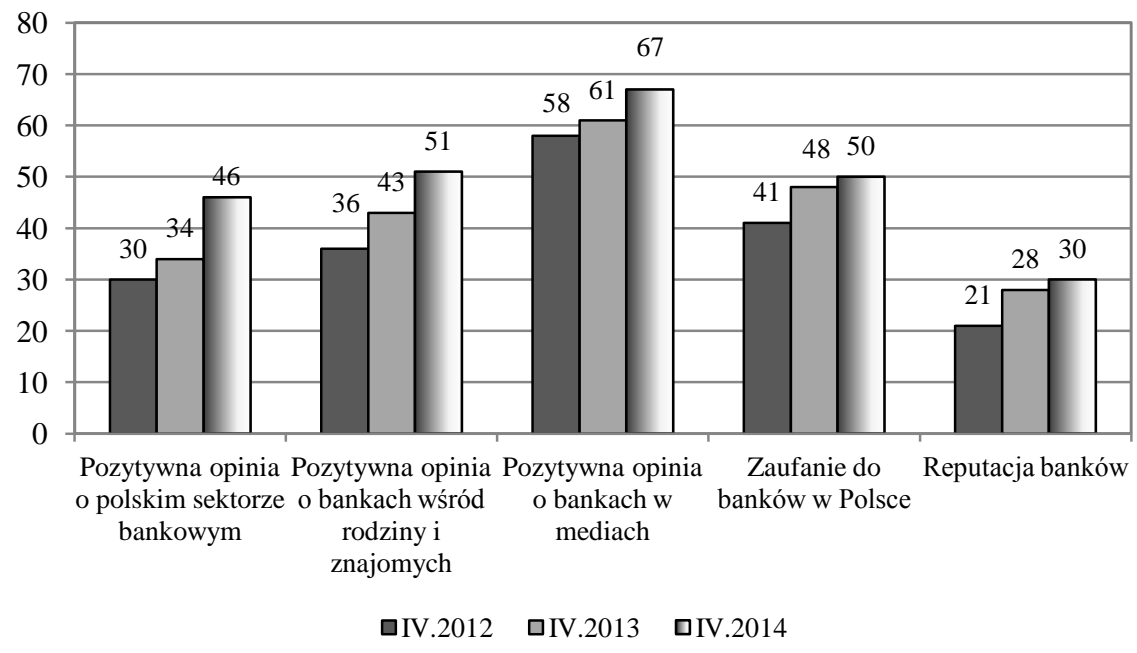

Wykres 2. Opinia społeczeństwa na temat sektora bankowego i zaufania do banków na przestrzeni lat 2012-2014 (w \% odpowiedzi)

Źródło: jak do wykresu 1, s. 11. 
Zaufanie jest pojęciem niejednorodnym, zmiennym w czasie i uzależnionym od wielu czynników. Co ciekawe, wśród wielu instytucji banki działające na terenie Polski w znacznym stopniu cieszą się zaufaniem społeczeństwa i przedsiębiorców (w 2014 r. 60\% polskiego społeczeństwa potwierdzała zaufanie do banków, z których korzysta badany, wśród przedsiębiorców wartość tego wskaźnika oscylowała na poziomie $95 \%$ - zob. wykresy 3 i 4). W obu przypadkach zaufanie do znanej instytucji finansowej było wyższe od analogicznych mierników zaufania do Narodowego Banku Polskiego, banków działających w Polsce, Europie czy na świecie. Zaufanie przedsiębiorców do instytucji jest wyższe niż w przypadku osób fizycznych, co może wynikać z różnic w zakresie oferty produktowej oraz jakości obsługi.

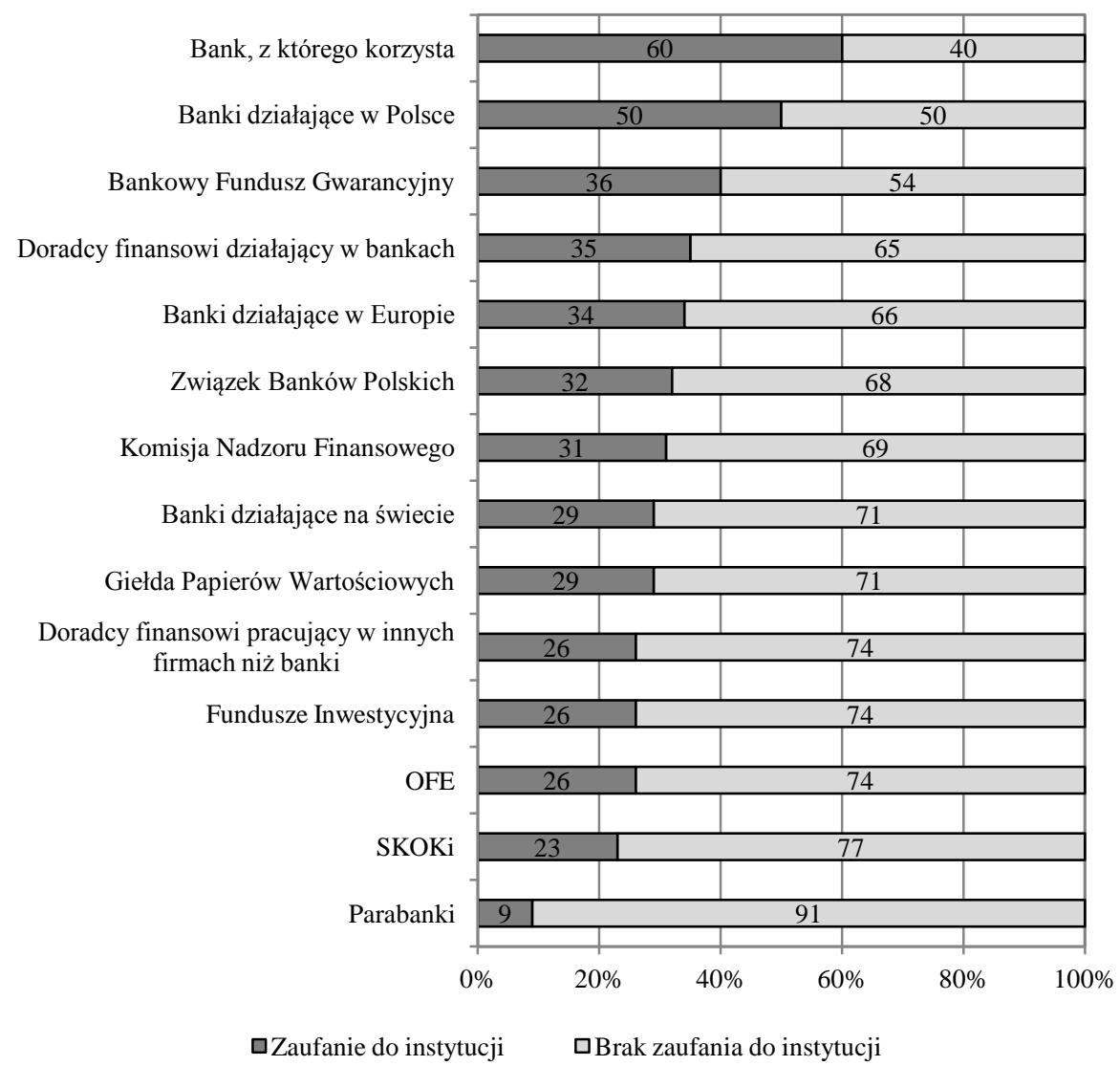

Wykres 3. Zaufanie społeczeństwa do instytucji (w \% odpowiedzi)

Źródło: jak do wykresu 1, s. 5. 


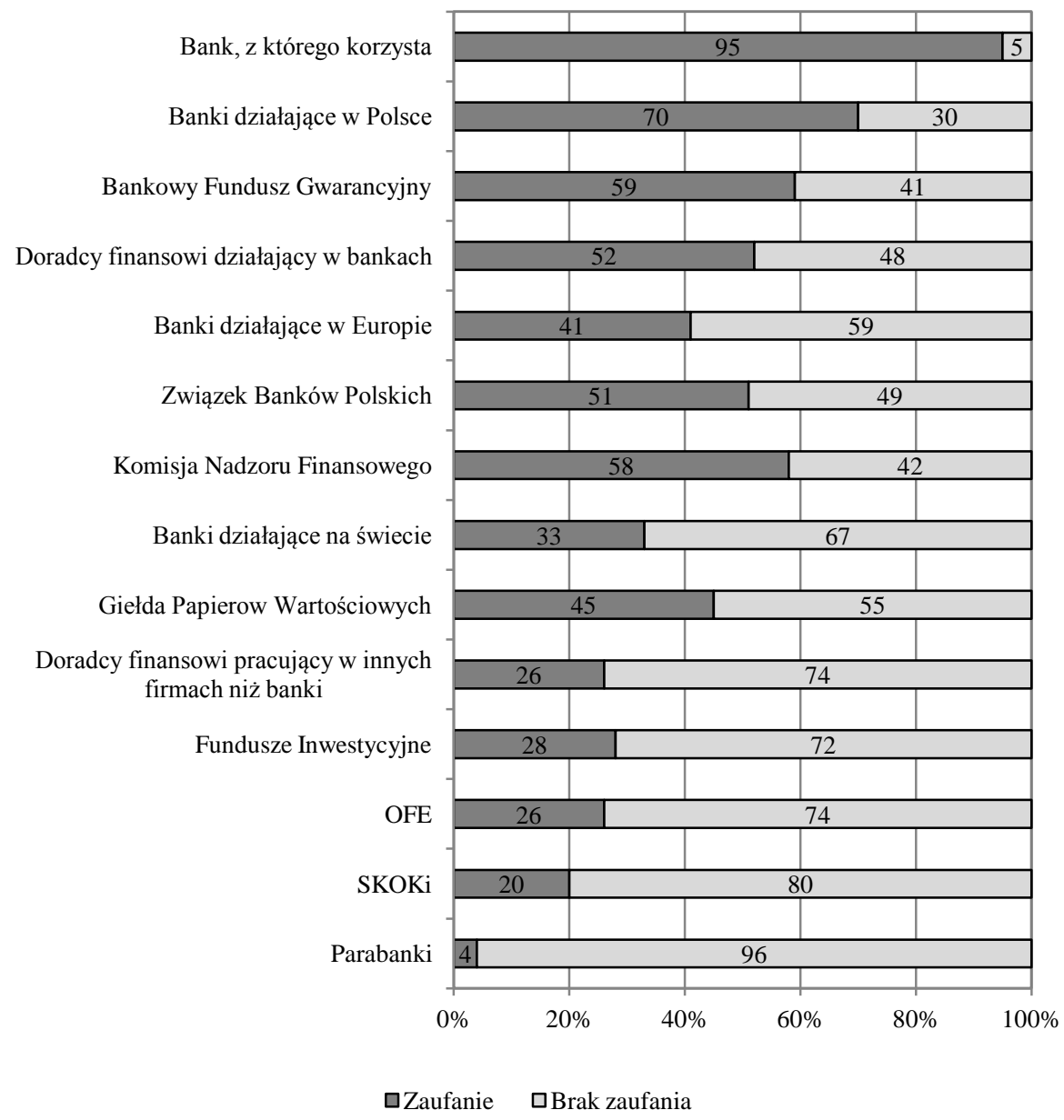

Wykres 4. Zaufanie przedsiębiorców do instytucji (w \% odpowiedzi)

Źródło: jak do wykresu 1, s. 6.

Co istotne, klienci decydują się na wybór danego banku przede wszystkim ze względu na to, że jest on pewny i godny zaufania ( $27 \%$ klientów detalicznych jest tego zdania oraz 36\% klientów segmentu Private banking - zob. wykres 5). Jest to szczególnie istotny wniosek biorąc pod uwagę pozostałe różnice w czynnikach determinujących decyzję o skorzystaniu z usług danej instytucji w grupie klientów detalicznych i zamożnych - w pierwszym przypadku duże znaczenie ma cena produktów bankowych i ich dostępność, podczas gdy w drugim w dużej mierze jakość obsługi i dostępność. 


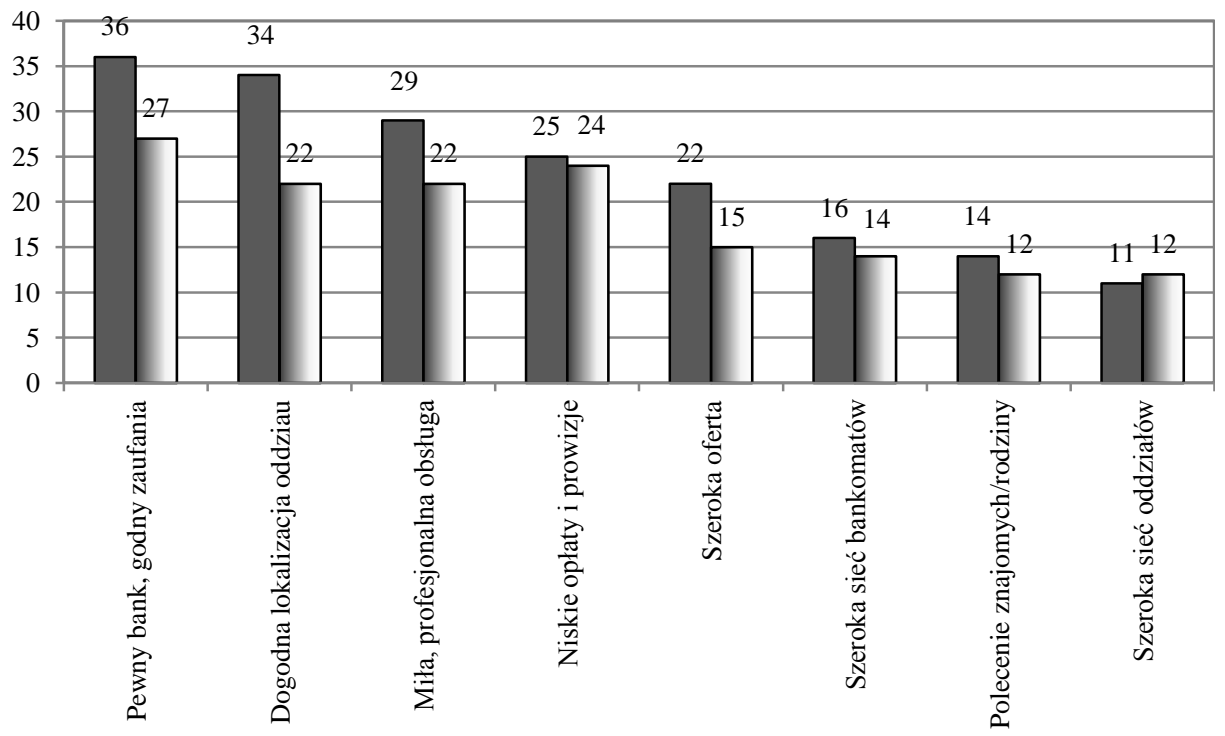

口Klienci zamożni $\quad$ Klienci detaliczni

Wykres 5. Czynniki determinujące wybór banku przez klientów zamożnych i detalicznych (w \% odpowiedzi)

Źródło: jak do wykresu 1, s. 7.

Chęć zarobienia na niewiedzy klienta Chęć zarobienia coraz większych kwot na klientach

Krótki czas działania na rynku

Wprowadzanie niezrozumiałych skomplikowanych ofert

Brak informacji o zmianach w ofercie

Intensywna reklama

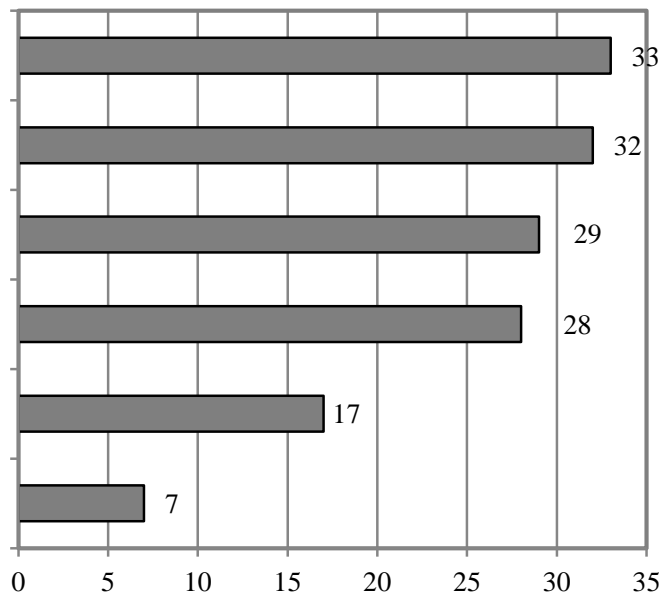

Wykres 6. Czynniki obniżające spadek zaufania klientów do banków (w \% odpowiedzi) Źródło: jak do wykresu 1, s. 7. 
W 2014 r. 60\% społeczeństwa twierdziło, że nie wszystkie banki są jednakowo godne zaufania, zaś analogiczne wskaźniki dla roku 2013 i 2012 wyniosły $56 \%$ i 46\%. Zauważona tendencja może świadczyć o wzroście świadomości klientów w zakresie przestrzegania przepisów prawnych i zasad etycznych. Wśród najistotniejszych czynników decydujących o nieobdarzaniu zaufaniem instytucji finansowych należy wymienić: chęć zarobienia na niewiedzy klienta (33\% odpowiedzi), chęć zarobienia coraz większych kwot na kliencie (32\% odpowiedzi), krótki czas działania na rynku (29\% odpowiedzi), wprowadzanie skomplikowanych i niezrozumiałych ofert ( $28 \%$ odpowiedzi) i nie informowanie o zmianach w ofercie (wykres 6).

\section{PODSUMOWANIE}

Banki jako instytucje pośrednictwa finansowego pełnią ważną rolę w systemie finansowym, ponieważ zapewniają obrót instrumentów finansowych, przejmują na siebie ryzyko, pośredniczą w przepływie kapitału i informacji, a także budują sieć bezpieczeństwa finansowego. System finansowy powinien być nie tylko efektywny, ale także uczciwy i stabilny, zaś pomiędzy tymi cechami zachodzi zależność dwustronna, tzn. system finansowy jest efektywny, gdy jest uczciwy i stabilny (bo klienci mają zaufanie do banków i powierzają im swoje depozyty), ale z drugiej strony musi być on efektywny, żeby mógł prowadzić swoją działalność w sposób uczciwy i stabilny. Każda z tych cech jest uzależniona od innych elementów systemu bankowego - stabilność zależy od sprawności i powszechności systemu rozliczeń bankowych oraz skuteczności działań nadzorczych, efektywność od optymalizacji kosztów i przychodów, stopnia zaangażowania instytucji finansowych w alokację wolnych kapitałów i stopień otwartości krajowego systemu finansowego, zaś na uczciwość mają wpływ takie czynniki jak: zapewnienie odpowiedniego poziomu konkurencji, zagwarantowanie ochrony przed wykorzystaniem niewiedzy konsumentów i zapobieganie konfliktom interesów ${ }^{61}$.

Przeprowadzona analiza typu desk research pokazała, że zaufanie do banków zmniejsza się w okresie kryzysu finansowego, jednakże w znacznej mierze klienci ufają instytucjom, którym powierzają swoje oszczędności. Należy przy tym wskazać, że nieetyczne zachowania, jak np. celowe wprowadzanie w błąd, obniża zaufanie konsumentów. Jednak wybierając bank, klienci przede wszystkim kierują się tym, czy jest on pewny i godny zaufania, co oznacza, że jest to dla nich najwyższa wartość oraz fundament działania banków jako instytucji zaufania publicznego.

\footnotetext{
${ }^{61}$ S. Flejterski, op. cit., s. $109-110$
} 


\section{BIBLIOGRAFIA}

Allport G. W., Pattern and Growth in Personality, Holt, Rinehart and Winston, New York 1961.

Bandura A., Teoria społecznego uczenia sie, Wydawnictwo Naukowe PWN, Warszawa 2007.

Barber B., The Logic and Limits of Trust, Rutgers University Press, New Brunswick 1983.

Bączyk M., Góral L., Fojcik-Mastalska E. (red.), Prawo bankowe. Komentarz, Wydawnictwo Prawo i Gospodarka, Warszawa 2005.

Bocheński J., Filozofia przedsiębiorstwa, [w:] J. Bocheński (red.), Sens życia i inne eseje, Wydawnictwo Antyk, Kraków 1993.

Cattell R. B., The Scientific Analysis of Personality, Penguin Books, Baltimore 1965.

Cohen J., Trust, Voluntary Association and Workable Democracy, [w:] M. E. Warren (ed.), Democracy and Trust, Cambridge University Press, Cambridge 1999.

Coleman J. S., Foundations of Social Theory, Harvard University Press, Cambridge 1990.

Coleman J. S., Social Capital in the Creation of Human Capital, „American Journal of Sociology” 1988, vol. 94.

Coote L., Forrest E. J., Tam T. W., An Investigation into Commitment in Non-Western Industrial Marketing Relationships, „Industrial Marketing Management” 2003, vol. 32(7).

Czarnota D., Bank jako instytucja zaufania publicznego w dobie kryzysu - mit czy rzeczywistość?, „Zeszyty Naukowe Wydziałowe Uniwersytetu Ekonomicznego w Katowicach. Studia Ekonomiczne" 2014, nr 186.

Dąbrowska M., Bank jako instytucja zaufania publicznego, „Bezpieczny bank” 2002, nr 2-3 (17-18).

Delhey J., Newton K., Who Trusts? The Origins of Social Trust in Seven Societies, „European Societies" 2003, no. 5(2).

Earle T. C., Cvetkovich G., Social Trust: Towards a Cosmopolitan Society, Praeger, Westport 1995.

Erikson E. H., Childhood and Society, Norton, New York 1950.

Flejterski S., W poszukiwaniu nowego paradygmatu zarządzania przedsiębiorstwem bankowym, [w:] A. Panasiuk, K. Rogoziński (red.), Zarządzanie organizacjami ustugowymi, Wydawnictwo Uniwersytetu Ekonomicznego w Poznaniu, Poznań 2009.

Fukuyama F., Zaufanie. Kapitat społeczny a droga do dobrobytu, Wydawnictwo Naukowe PWN, Warszawa 1997.

Fojcik-Mastalska E., Prawo bakowe. Komentarz, LexisNexis, Warszawa 2005.

Frykowski M., Zaufanie społeczne mieszkańców Łodzi, Wydawnictwo Uniwersytetu Łódzkiego, Łódź 2005.

Gałkowski J. W., Zasady etyki zawodowej - etyka biznesu, [w:] M. Borkowska, J. W. Gałkowski (red.), Etyka w biznesie, TN KUL, Lublin 2002.

Głuchowski J., Szambelańczyk J., Bankowość: podręcznik dla studentów, Wydawnictwo Wyższej Szkoły Bankowej, Poznań 1999.

Głuszek E., Zaufanie jako istotny sktadnik kapitału intelektualnego przedsiębiorstwa, „Prace Naukowe Akademii Ekonomicznej we Wrocławiu” 2002, nr 963.

Góral L., Nadzór bankowy, PWE, Warszawa 1998.

Górniok O. (red.), Prawo karne gospodarcze. Prawo gospodarcze i handlowe, C. H. Beck, Warszawa 2003.

Guiso L., Sapienza P., Zingales L., Social Capital as Good Culture, „Journal of the European Economic Association" 2008, vol. 6, no. 2-3.

Hardin R., Zaufanie, Wydawnictwo Sic, Warszawa 2009.

Hardin R., Trust and Trustworthiness, Russell Sage Foundation, New York 2002.

Hardin R., The Street-level Epistemology of Trust, „Politics and Society” 1993, no. 21, December.

Hooghe M., Value Congruence within Voluntary Associations: Ethnocentrism in Belgian Organisations, Paper presented to the ECPR Joint Sessions of Workshops, Copenhagen 2000. 
House J. S., Wolf Sh., Effects of Urban Residence on Interpersonal Trust and Helping Behavior, „Journal of Personality and Social Psychology” 1978, no. 36.

Inglehart R., Trust, Well-being and Democracy, [w:] M. E. Warren (red.), Democracy and Trust, Cambridge University Press, Cambridge 1999.

Iwanicz-Drozdowska M., Typologia i tendencje rozwojowe systemów gwarantowania depozytów, [w:] M. Iwanicz-Drozdowska (red.), Systemy gwarantowania depozytów w Polsce i na świecie, PWE, Warszawa 2005.

Janiak A., O przywilejach bankowych. Cz. III, „Prawo Bankowe” 2000, nr 11.

Kałużny R., Skutki kryzysu. Nowe spojrzenie na rolę banków, [w:] A. Janc (red.), Bankowość a kryzys na rynkach finansowych, Wydawnictwo Uniwersytetu Ekonomicznego w Poznaniu, Poznań 2010.

Katz M. B., Essay Review: Family Structure in Nineteenth Century Lancashire. By Michael Anderson, „Journal of Social History” 1973, vol. 7, no. 1.

Knack S., Keefer Ph., Does Social Capital Have an Economic Payoff? A Cross-country Investigation, „Quarterly Journal of Economics” 1997, no. 112.

Kodeks Etyki Bankowej, Związek Banków Polskich, Warszawa 2013.

Kosikowski C., Dzwonkowski H., Huchla A., Ustawa Ordynacja podatkowa. Komentarz, C. H. Beck, Warszawa 2002.

Lin N., Social Capital. A Theory of Social Structure and Action, Cambridge University Press, Cambridge 2001.

Majewski J., Prawo karne gospodarcze, [w:] O. Górniok (red.), Prawo karne gospodarcze. Prawo gospodarcze i handlowe, C. H. Beck, Warszawa 2003.

Masiukiewicz P., Rola państwa w przezwyciężaniu kryzysu banku, [w:] J. Szambelańczyk (red.), Globalny kryzys finansowy i jego konsekwencje w opiniach ekonomistów polskich, Związek Banków Polskich, Warszawa 2009.

Matysiak A., Źródła kapitału społecznego, Wydawnictwo Akademii Ekonomicznej we Wrocławiu, Wrocław 1999.

Misztal B., Trust in Modern Societies: The Search for the Bases of Social Order, „Theory and Society", vol. 28, no. 2.

Newton K., Social Capital and Democracy in Modern Europe, [w:] J. van Deth, M. Maraffi, K. Newton, P. Whiteley (red.), Social Capital and European Democracy, Routledge, London 1999.

Newton K., Trust, Social Capital, Civil Society, and Democracy, „International Political Science Review" 2001, no. 22(2).

North D., Institutions, Institutional Change and Economic Performance, Cambrigde University Press, New York 1990.

Ofiarski Z., Prawo bankowe, Kantor Wydawniczy Zakamycze, Zakamycze 2004.

Olson M., The Rise and Decline of Nations: Economic Growth, Stagflation and Social Rigidities, Yale University Press, New Haven 1982.

Orren G., Fall from Grace: The Public's Loss of Faith in Government, [w:] J. S. Nye, Ph. D. Zelikow, D. C. King (red.), Why Americans Mistrust Government, Harvard University Press, Cambridge 1997.

Osiński J., Stabilność finansowa w Polsce - aspekty finansowe, „Bank i Kredyt” 2005, nr 11-12.

Patterson O., Liberty Against the Democratic State: On the Historical and Contemporary Sources of American Distrust, [w:] M. E. Warren (ed.), Democracy and Trust, Cambridge University Press, Cambridge 1999.

Paxton P., Social Capital and Democracy: An Interdependent Relationship, „American Sociological Review" 2002, no. 67.

Pietrzak B., Polański Z. (red.), System finansowy w Polsce, Wydawnictwo Naukowe PWN, Warszawa 1998. 
Pitera J., Charakterystyka instytucji zaufania publicznego w orzecznictwie Trybunatu Konstytucyjnego, Sąu Najwyższego oraz Sąów Powszechnych, „Kwartalnik Prawa Publicznego” 2007, nr 4.

Putnam R., Bowling Alone, The Collapse and Revival of American Community, Simon and Schuster, New York 2000.

Putnam R., Demokracja $w$ działaniu: tradycje obywatelskie we wspótczesnych Włoszech, Znak, Kraków 1995.

Radziszewski E., Bank jako instytucja zaufania publicznego. Gwarancje prawne i instytucjonalne, KNF, Warszawa 2013.

Rosenberg M., Misanthropy and Attitudes Towards International Affairs, „Journal of Conflict Resolution" 1957, no. 1.

Rosenberg M., Misanthropy and Political Ideology, „American Sociological Review” 1956, no. 21.

Santomero A., Deposit Insurance: Do We Need It and Why, The Wharton School, University of Pensylvania, Pensylvania 1997.

Schudson M., What If Civic Life Didn't Die?, „The American Prospect” 1996, no. 25, March-April.

Sekuła J., Uprawomocnienie tzw. etyki biznesu w systemie etyki graduacyjnej, [w:] A. Węgrzecki (red.), Etyczne fundamenty gospodarowania, Oficyna Cracovia, Kraków 1999.

Smith A., Badania nad natura i przyczynami bogactwa narodów, t. 2, PWN, Warszawa 1954.

Sobol E. (red.), Nowy słownik języka polskiego, Wydawnictwo Naukowe PWN, Warszawa 2002.

Stenberg E., Czysty biznes. Etyka w działaniu, Wydawnictwo Naukowe PWN, Warszawa 1998.

Sztompka P., Zaufanie. Fundament społeczeństwa, Znak, Kraków 2007.

Sztompka P., Socjologia. Analiza społeczeństwa, Znak, Kraków 2002.

Sztompka P., Trust. The Sociological Theory, Cambridge University Press, Cambridge 1999.

Uchwała Izby Cywilnej SN z 30.04.1999 r., III CZP 61/98, OSNC 1999, nr 12, poz. 201.

Uslander E. C., Zaufanie strategiczne i zaufanie normatywne, [w:] P. Sztompka, M. BoguniBorowska (red.), Socjologia codzienności, Znak, Kraków 2008.

Uslaner E. M., The Moral Foundations of Trust, Cambridge University Press, Cambridge 2002.

Uslaner E. M., Producing and Consuming Trust, „Political Science Quarterly” 2000, no. 115(4).

Uslaner E. M., Democracy and Social Capital, [w:] M. Warren (red.), Democracy and Trust, Cambridge University Press, Cambridge 1999.

Ustawa z dnia 29 lipca 2005 r. o nadzorze nad rynkiem kapitałowym, DzU 2005, nr 183, poz. 1537 , ze zm.

Ustawa z dnia 29 lipca 2005 r. o obrocie instrumentami finansowymi, DzU 2005, nr 183, poz. 1538 , ze zm.

Ustawa z dnia 16 listopada 2000 r. o przeciwdzialaniu praniu pieniędzy oraz finansowaniu terrorуzтu, DzU 2000, nr 116, poz. 1216, ze zm.

Ustawa z dnia 6 czerwca 1997 r. Prawo karne, DzU 1997, nr 88, poz. 553, ze zm.

Ustawa z dnia 14 grudnia 1994 r. o Bankowym Funduszu Gwarancyjnym, DzU 1994, nr 4, poz. 18, ze zm.

Verba S., Schlozman K. L., Brady H. E., Voice and Equality: Civic Volunteerism in American Politics, Harvard University Press, Cambridge 1995.

Walczak-Duraj D., Socjologia dla ekonomistów, PWE, Warszawa 2010.

Whiteley P. F., The Origins of Social Capital, [w:] J. van Deth, M. Maraffi, K. Newton, P. Whiteley (red.), Social Capital and European Democracy, Routledge, London 1999.

Wizerunek polskiego sektora bankowego. Edycja 2014, TNS Polska dla Związku Banków Polskich, Warszawa 2014.

Wyrok Trybunału Konstytucyjnego z 18.04.2000 r., K 23/99, „Glosa” 2000, nr 12.

Yamagishi T., Yamagishi M., Trust and Commitment in The United States and Japan, „Motivation and Emotion" 1993, no. 18(2).

Zdanowicz B., Podstawowe dylematy i kryteria wyboru formuly systemu gwarantowania depozytów w świetle teorii i doświadczeń międzynarodowych, „Bezpieczny Bank” 2007, nr 1(34).

Zoll F. (red.), Prawo bankowe. Komentarz, Kantor Wydawniczy Zakamycze, Zakamycze 2005. 


\title{
TRUST IN THE BANKING SECTOR
}

\begin{abstract}
Trust is the foundation of relation between advisers and clients, but above all, it is the capital needed for the functioning of banks as an institution of public trust. The purpose of this paper is an attempt to place public confidence in the theory and analysis of public opinion about the banking sector as well as the necessary basis of trust with financial institutions.
\end{abstract}

Keywords: trust, banks, institution of public trust. 